\title{
Valorization of By-Products from Commercial Tuna Cannery for New Formulation of Pet's Food Product: Physicochemical Characterization and DLC Determination
}

\author{
Aida karray*, Ameni ktata, Naima mounedi and Adel Sayari \\ Laboratoire de Biochimie et de Génie Enzymatique des Lipases, Tunisia \\ *Corresponding author: Aida Karray, Laboratoire de Biochimie et de Génie Enzymatique des Lipases, ENIS Route de \\ Soukra, université de Sfax-Tunisia
}

\section{ARTICLE INFO}

Received: 㗀 July 17, 2020

Published: 幽 July 28, 2020

Citation: Aida karray, Ameni ktata, Naima mounedi, Adel Sayari. Valorization of ByProducts from Commercial Tuna Cannery for New Formulation of Pet's Food Product: Physicochemical Characterization and DLC Determination. Biomed J Sci \& Tech Res 29(1)-2020. BJSTR. MS.ID.004759.

Keywords: Valorization; Discarded Species of Tuna; Wet Pet Foods; Expiration Date

\section{ABSTRACT}

Tunisia has natural resources favorable to fishing with a coastline that extends for a total length of 1,300 kilometers. The large quantities processed show that tuna canneries generate an important amount of discarded high-quality species. These wastes are, of course, problems, but they also offer excellent opportunities for biotechnological exploitation. The disposal of these wastes has always been expansive and has often a harmful impact on the environment, but thanks to the evolution of techniques and the development of markets, it is now possible to transform this waste stream into useful and marketable products. Thanks to their high protein content, tuna discarded products represent an important source for the development of a new animal feed product, including the young dog. In the present work, we focused primary on the characterization of the red muscles of a tuna cannery for inclusion in the formulation of young dog's wet food. The composition of these co-products indicates a high protein content $(80 \%)$, and a moderate fat and mineral content $(11 \%$ and $8 \%$, respectively). Nevertheless, the carbohydrate content in the red muscles of this fish remains low (2\%). To increase the carbohydrate content which constitute the principal energy source and fiber proportion to improve product digestibility by the animals, cereals (maize flour and rice flour) were used. Four formulae were tested, using the same manufacturing process. A physicochemical study of the finished products was carried out and the Limit Date of Consumption was determined and estimated to 3 years and 3 months.

\section{Introduction}

Over the past five decades, world fish production has progressively increased and the amount of fish for consumption has increased with an average annual growth rate of 3,2\%, a higher rate than the global population, which stood at $1.6 \%$ [1]. In 2011, total global fishing accounted for 154 million tons of fish (91.6 million tons of fish and marine animals from capture and 62.4 million tons from aquaculture) [2]. The differences in the arrangement of sea food products concern all fresh products which are damaged when caught and fished, transported, handled or removed after sorting in packing plants, freezing or canning of fish. In general, about half of the world's catches are consumed directly by humans. The fish processing industry is responsible for a huge amount of wastes, including skins, bones, fins, scales, and swim bladders, representing nearly $36 \%$ (and may represent up to 60\%) of the raw material mass [3]. Given that ecological laws restricting the removal of fish discards are increasing, there is a strong demand towards the complete exploitation of marine resources. These releases contain high-nutritional protein, unsaturated fatty acids, vitamins, antioxidants, minerals, and essential amino acids and peptides that are beneficial to the body. It is therefore essential to find ways of 
making the most of these co-products by integrating the concept of sustainable development: the techniques used must be nonaggressive to the environment and must not involve excessive energy expenditure or investment [4]. Today, the fisheries resource development industry is a future component of the fishing industry.

The added value of these products is its contribution to reducing the loss of valuable protein. It may also be the source of new products [5]. Potential field of applications are very broad [6,7]. The most prevalent field is the use for human or pet food. The second is dietary and nutraceutical ingredients. The third is cosmetic and pharmaceutical ingredients and the latter covers various fields of application (agriculture, energy, leather, industry, etc.). The present study concerns the valorization of fishery products and aims at the development of food for young dogs and cats from red muscle co-products, resulting from the processing of tuna. The marine coproduct advancement industry is part of the fish industry branch of the IAA sector. It is also included in the list of primary agricultural processing activities JORT [8]. In fact, valorization is of big interest to both the canned and semi-preserved fish industry, the frozen seafood industry, and the fish-based food industry. The valorization of fish muscle proteins from high quality discarded species has been studied, and these proteins are considered suitable for the preparation of different seafood products with enhanced added value in comparison to the traditional preparation of fish meals or fish oils [9-11]. However, we investigate the physicochemical characterization of the red muscles of tuna revealed the richness of these co-products in protein, minerals and fat. The use of these co-products in Tunisia is extremely rare and is limited to the manufacture of fish meal. The incorporation of these red muscles with cereals and sunflower oil in wet foods for young dogs has made it possible to have balanced and stable foods. A physicochemical study of the finished products was carried out and the Limit Date of Consumption was determined and estimated to 3 years and 3 months.

\section{Materials and Methods}

\section{Raw Material}

The selected fish species "Atlantique red thon" (Thunnus Thynnus) "yellow thon" (Thunnus albacares) and "pink thon" named also Skip Jack Tuna (Katsuwonus pelamis) were collected from local tuna cannery. Twenty $\mathrm{kg}$ of each selected species was separated from commercial ones and distributed in $12 \mathrm{~kg}$ iced boxes until further processing. Rice flour, corn flour and sunflower oil were purchased from a local provider.

\section{Physicochemical Characterization}

\section{Determination of the Ashes}

The percentage of residue is determined by calcinating $1 \mathrm{~g}$ of dried sample in triplicata for 4 hours at $550^{\circ} \mathrm{C}$ to constant mass [12].

\section{Minerals Determination}

The resulting residues were treated with $5 \mathrm{ml}$ of nitric acid and $5 \mathrm{ml}$ of concentrated chloric acid, the solution is heated until white smoke is released and the acids evaporate. $15 \mathrm{ml}$ of distilled water is added, while continuing the heating for $10 \mathrm{~min}$. The solution was filtered in a $50 \mathrm{ml}$ flask and the volume completed by the distilled water. Mineral contents ( $\mathrm{K}, \mathrm{Mg}, \mathrm{Ca}, \mathrm{Na}, \mathrm{Zn}$ and $\mathrm{Fe}$ ) were determined by atomic absorption according to the Officials methods of analysis [13].

\section{Determination of Proteins by the Kjeldahl Method:}

The percentage of total nitrogen is expressed using the standard Kjeldahl method. The protein assay is based on a mineralization of organic matter then a distillation and titration with $0,1 \mathrm{~N}$ sulphuric acid [14]. Protein $(\%)=\left(\left(\mathrm{N}^{*} \mathrm{~V}^{*} 14^{*} 100\right) / \mathrm{m}\right)$ 6.25V: Volume of sulphuric acid $0,1 \mathrm{~N}(\mathrm{ml}) ; \mathrm{N}$ : Title of sulphuric acid solution $(0,1 \mathrm{~N})$; $\mathrm{m}=$ mass of sample analyzed in $\mathrm{mg} ; 6,25$ : Coefficient of conversion of organic nitrogen into proteins. This factor is since proteins contain an average of $16 \%$ nitrogen.

\section{Lipids}

Extraction of the fat in the sample was performed using the Soxhlet technique, using petroleum ether as an organic solvent [14].

\section{Assays}

Fatty acids were methylated by boron trifluoride in methanol (Sigma) according to the Metchalfe and Schmitz [15] method. The Rapid Preparation of Fatty Acid Esters for Gas Chromatographic Analysis [16] and fatty acid methyl esters (FAMEs) were analyzed by gas chromatography (GC) on a Shimadzu (GC-2014) equipped with non-polar DANI-SPA column (50m length, $0.32 \mathrm{~mm}$ i.d.) and a flame ionization detector. Nitrogen was used as a carrier gas. The temperatures of the column oven, the injection ports, and the detector were maintained at 165,250 , and $250^{\circ} \mathrm{C}$, respectively. Two microliters of the sample were injected into the column. Chromatographic peaks were identified by comparing the retention times with those of known standards, maintained at 165, 250, and $250^{\circ} \mathrm{C}$, respectively. Two microliters of the sample were injected into the column. Chromatographic peaks were identified by comparing the retention times with those of known standards.

\section{Determination of total Sugar Content}

Total sugars were determined using the method described by Dubois et al. [17]. Optical density (DO) was measured at 490nm.

\section{DLC Determination Test}

The protocols for performing the DLC analyses or aging tests are described in the French standard NF V 01-003 [18] of February 2004. The principle is to keep a number of product units, by varying the temperature to create a "cold chain break" that will result in an increase in the different reactions leading to aging of the product and periodically we count the total germs. The resolution of 
Arrhenius' law, allows calculating the microbiological DLC of the products tested.

$$
r=\frac{d[A]}{d t}=K[A]^{n}
$$

r: degradation rate; A: Parameter to be studied; K: Speed constant of the reaction; $\mathrm{n}$ : Order of reaction

Reaction of order 0 : $\mathrm{A}-\mathrm{A} 0=\mathrm{kt}$, characterized by a linear relationship between the deterioration and reaction time. Reaction of order $1: \ln (\mathrm{A} 0 / \mathrm{A})=\mathrm{kt}$, characterized by a logarithmic change in the A concentration as a function of time. Order reaction n: 1/A n-1 $-1 / A 0 \mathrm{n}-1=\mathrm{kt}$, with: A0 the initial value of factor $\mathrm{A}$ on the day of its manufacture.

\section{Results and Discussion}

\section{1-Physicochemical Characterization of Tuna Red Muscles:}

Table 1: Physiochemical composition of red tuna muscles (\%).

\begin{tabular}{|c|c|c|c|c|c|c|}
\hline & Moisture (\%) & Ashes (\%) & Proteins $^{\mathbf{a}}$ & Lipids $^{\mathbf{a}}$ & Minerals $^{\mathbf{a}}$ & Sugare $^{\mathbf{a}}$ \\
\hline Muscle rouge $^{\mathrm{a}}$ & $75,356 \pm$ & $38,48 \pm$ & $80,09 \pm$ & $11.3 \pm$ & $7.67 \pm$ & $1.55 \pm$ \\
\hline (\% MS) & 0.33 & 0.56 & 0.65 & 0.03 & 0.009 & 0.11 \\
\hline
\end{tabular}

Table 2a: CPG analyses of the lipid fraction of tuna's red muscles.

\begin{tabular}{|c|c|}
\hline Fatty acids & (\%) in the lipid fraction of the red muscles \\
\hline$\Sigma$ A.G.S & 25.83 \\
\hline $\mathrm{C}_{12: 0}$ & 5.64 \\
\hline $\mathrm{C}_{14: 0}$ & 1.41 \\
\hline $\mathrm{C}_{16: 0}$ & 4.92 \\
\hline $\mathrm{C}_{18: 0}$ & 13.86 \\
\hline$\Sigma$ A.G.M.I & 74.17 \\
\hline $\mathrm{C}_{16: 1}$ & 47.63 \\
\hline $\mathrm{C}_{18: 1}$ & 26.54 \\
\hline
\end{tabular}

Table 2b: Red muscle minerals and trace elements (mg/100g).

\begin{tabular}{|c|c|}
\hline Minéraux & Teneurs \\
\hline Calcium & 0,36 \\
\hline Potassium & 170.15 \\
\hline Sodium & 240.6 \\
\hline Magnésium & 100.2 \\
\hline Fer & 0.48 \\
\hline Cuivre & $<0.001$ \\
\hline Zinc & 0.28 \\
\hline
\end{tabular}

Characterization of the raw material is essential before any investigation into the formulation of a food product. In fact, the composition of primary material is critical to choose the suitable product to develop. The physicochemical characterization of tuna red muscles includes a dry matter, fat, protein and minerals is presented in Table 1 . The results show that the red muscles have a high moisture content reaching around 75\%. This could

\section{Apparent Rate of Deterioration Constant (K):}

The relationship between $\mathrm{K}$ and temperature $\mathrm{T}$ is as shown in equation (2)

$$
K=K 0 * \exp \left(\frac{-E a}{R^{*} T}\right)
$$

K: The speed apparent constant at temperature T; K0: The constant independent temperature; Ea: Activation energy (cal/g/ mol) or free energy activation: this is the energy that must be supplied to the reagents (heat, UV radiation,.) so that they can react to form products. Reagents must reach a transition state in which the bonds are more fragile, the activation energy corresponds to energy between initial and transient state; R: The perfect gas constant $(1,987 \mathrm{cal} / \mathrm{g} / \mathrm{mol} \mathrm{K})$; $\mathrm{T}$ : Absolute temperature $\left({ }^{\circ} \mathrm{K}\right)$. 
of these red muscles in unsaturated fat, the fatty acid composition of the fat fraction of the co-products was achieved and presented in the Table 2a. Red muscle contains a diversity of fatty acids in the lipid fraction. It contains a moderate content of saturated fatty acids (26\%) compared to beef (46\%) and lamb (51\%) (20), whose excess of this type of fat increases cardiovascular risk. In addition, it is an appreciable source of monounsaturated fat (74\%). For food application, further characterization of the mineral composition is required. The results are summarized in Table $2 \mathrm{~b}$. Tuna red muscles contain high amounts of sodium $(240 \mathrm{mg} / 100 \mathrm{~g}$ MS) and potassium $(170 \mathrm{mg} / 100 \mathrm{~g}$ MS). The magnesium concentration is in the order of $100 \mathrm{mg} / 100 \mathrm{~g}$, which is significantly higher (4 times higher) than those described for beef (24mg/100g) [19] or shrimp (61mg/100g) [20].

\section{Formulation of a New Young Dog's Food Product:}

Based on the physio-chemical characterization of the red muscles of the tuna cannery and considering the nutritional needs of the young dog, four different food formulas wish would differ only by the proportion of cooked tuna co-products were prepared. The raw material being the portions of the red tuna muscles, the other ingredients used in the formula are rice flour, corn flour, sunflower oil and water. The same characterization of the ingredients were performed (data not shown). The resulting of each formula is summarized in Tables 3 . The composition of the dog food products is determined by physio-chemical analyses to verify the different components required by the European standard INCO, which necessitates the display of the composition on the packaging of the product to be consumed.

Table 3: Formulation of wet food product for young dogs: experimental values.

\begin{tabular}{|c|c|c|c|c|c|}
\hline \multicolumn{5}{|c|}{ Experimental Values (\%) } \\
\hline $\begin{array}{c}\text { Formules/ \% des } \\
\text { nutriment }\end{array}$ & Muscles red tuna & corn flour & rice flour & sunflower oil & water \\
\hline F1 & 65 & 5 & 10 & 5 & 15 \\
\hline F2 & 67 & 5 & 10 & 5 & 13 \\
\hline F3 & 70 & 5 & 5 & 5 & 15 \\
\hline F4 & 70 & 5 & 10 & 5 & 10 \\
\hline
\end{tabular}

\section{Physicochemical Characterization of Prepared Formulae}

The experimental values (Table 5a) confirm that the formula 2,3 and 4 meet the standards required by the AAFCO [21] and the FEDIAF [22] in terms of amount of proteins and fat composition (Table 4). The third formulation present the highest moisture percentage. Meanwhile, formulation number 2 and 4 are richer in terms of dry matter, proteins and minerals matter, and shows the highest energy values. This allows us to validate the choice of these two formulations for further microbiological and physicochemical analysis. Their energy inputs represent respectively about $16 \%$ and $17 \%$ of the need daily energy (1297.16 kcal). Their mineral

Table 4: Composition of prepared dogs food product (\%). contents are represented in the Table 5a. In fact, some minerals and trace elements remain below the AAFCO requirements, such as calcium, copper and zinc. These deficiencies can be corrected by using mineral-vitamin complexes in food formulation. To highlight the nutritional benefits of these foods and their unsaturated fats, the fatty acid composition of the fat fraction has been achieved and presented in Table $5 \mathrm{~b}$. These two formulas contain a diversity of fatty acids in the fat fraction. They are rich in unsaturated fatty acids, especially oleic acid which accounts for $27 \%$ of formula 2 and about $39 \%$ of formula 4 . Formula 4 is a source of linoleic acid $(\Omega 6)$ (55.43\%) compared to $50.28 \%$ of formula 2 .

\begin{tabular}{|c|c|c|c|c|c|c|c|}
\hline Formulation & Moisture (\%) & Ashes (\%) & Proteines $^{\mathbf{a}}$ & lipids $^{\mathbf{a}}$ & minerals $^{\mathbf{a}}$ & sugar $^{\mathbf{a}}$ & VE $^{(1,95 \pm}$ \\
\hline 1 & $57.29 \pm 2,00$ & $40.55 \pm 1,055$ & $18.29 \pm 2,2$ & $6.72 \pm 0,31$ & $1,95 \pm 0,28$ & $15.66 \pm 1,83$ & 196.28 \\
\hline 2 & $58.92 \pm 1,03$ & $42.41 \pm 1,524$ & $23.62 \pm 0,8$ & $7.19 \pm 0,49$ & $2,21 \pm 0,5$ & $13.5 \pm 0,85$ & 213.19 \\
\hline 3 & $63.74 \pm 2,21$ & $38.52 \pm 0,85$ & $23.51 \pm 0,1$ & $6.23 \pm 0,51$ & $1,93 \pm 0,23$ & $12.13 \pm 0,98$ & 198.63 \\
\hline 4 & $57.33 \pm 1,88$ & $42.14 \pm 1,54$ & $27.12 \pm 2,5$ & $7.50 \pm 0,86$ & $2,1 \pm 0,35$ & $12.35 \pm 2,01$ & 225.38 \\
\hline & AAFCO (2014) & 60 & 30 & 22.5 & 0.58 & 3.6 & ND \\
\hline
\end{tabular}

$\mathrm{a}=\%$ of MS; VE: energy value in $\mathrm{kcal} / 100 \mathrm{~g}$ of the product.

Table 5a: Mineral and trace element content in formulation 2 and 4.

\begin{tabular}{|c|c|c|c|}
\hline Minéraux & $\mathbf{2}$ & $\mathbf{4}$ & AAFCO(\%) \\
\hline Calcium & 0.83 & 0.76 & 1 \\
\hline Potassium & 0.7 & 0.49 & 0,6 \\
\hline Sodium & 1.55 & 2.25 & 0.3 \\
\hline Magnésium & 0.14 & 0.18 & 0.06 \\
\hline
\end{tabular}




\begin{tabular}{|c|c|c|c|}
\hline Fer & 184 & 79.4 & 88 \\
\hline Cuivre & 4.9 & 5.1 & 12.4 \\
\hline Zinc & 69.8 & 97.4 & 100 \\
\hline
\end{tabular}

Table 5b.

\begin{tabular}{|c|c|c|}
\hline \multirow{2}{*}{ Fatty acids } & \multicolumn{2}{|c|}{ (\%) in lipids fraction of } \\
\hline & 2 & 4 \\
\hline \multicolumn{3}{|l|}{$\Sigma$ A.G.S } \\
\hline $\mathrm{C}_{12: 0}$ & 0.86 & 2.03 \\
\hline $\mathrm{C}_{14: 0}$ & 0.17 & 0.43 \\
\hline $\mathrm{C}_{16: 0}$ & 11.78 & 27.7 \\
\hline $\mathrm{C}_{18: 0}$ & 3.74 & 9.07 \\
\hline \multicolumn{3}{|l|}{$\Sigma$ A.G.I } \\
\hline $\mathrm{C}_{16: 1}$ & 0.66 & 0.96 \\
\hline $\mathrm{C}_{18: 1}$ & 26.67 & 39.01 \\
\hline $\mathrm{C}_{18: 2}$ & 50.28 & 55.43 \\
\hline $\mathrm{C}_{18: 3}$ & 0.83 & 0.37 \\
\hline $\mathrm{C}_{20: 1}$ & 0.25 & 1.37 \\
\hline $\mathrm{C}_{20: 2}$ & 0.36 & 1.11 \\
\hline $\mathrm{C}_{20: 4}$ & 0.32 & 0.22 \\
\hline $\mathrm{C}_{20: 5}$ & 0.87 & 0.66 \\
\hline $\mathrm{C}_{22: 6}$ & 3.14 & 3.5 \\
\hline
\end{tabular}

\section{Microbiological Stability Tests and DLC Determination}

The microbiological analysis includes total aerobic mesophyll flora, staphylococcus aureus, fecal and total coliforms, ad anaerbic sulfi to reducer flora. Results confirm that the products tested are of good microbiological quality and meet the requirements of the fish canning standard. Despite the relatively high value of water activity ( 0.941 and 0.916 for the F2 and F4, respectively), the reference germs are absent, this can be explained by the efficiency of the heat treatment at $116^{\circ} \mathrm{C}$ for one hour after the sterilization procedure $[23,24]$.

\section{Aging Test}

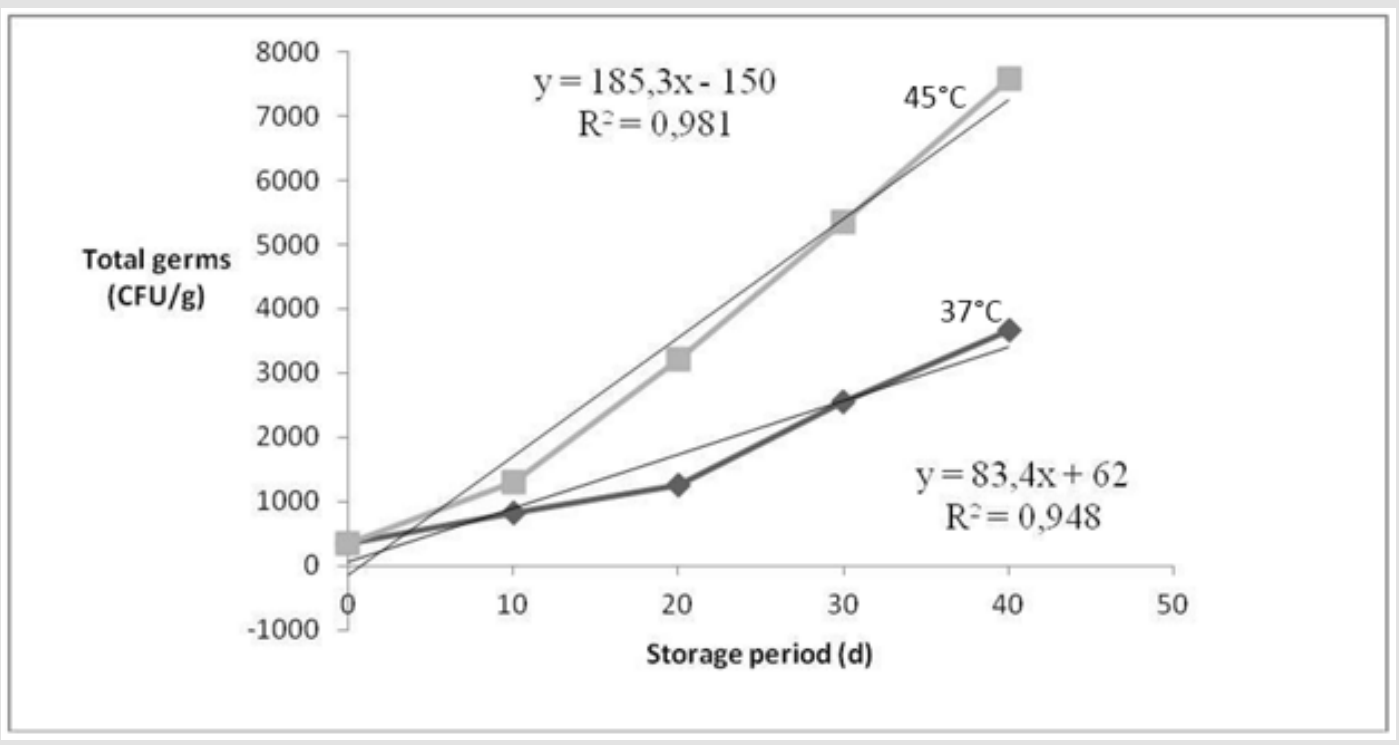

Figure 1a: Evolution of total germs over storage time at 37 and $45^{\circ} \mathrm{C}$. 
Measurement of total germs as a function of storage time and temperature $\left(37\right.$ and $\left.45^{\circ} \mathrm{C}\right)$ are reported in Figure 1. During storage, the total germ concentration increases linearly over time and temperatures rise, showing the positive effect of increasing temperatures $\left(37\right.$ to $45^{\circ} \mathrm{C}$ ) on the development of microorganisms. The linear regression lines representing number of germs as $f(t)$ shown in Figure 1a, gives regression coefficients R2 nearly of 1 . Degradation equations are of zero order of type: [GT]= [GT] $0+\mathrm{kt}$. This equation makes it possible to deduce the reaction constants at different temperatures: $\mathrm{K}=83.4$ and 185.3 at $37^{\circ} \mathrm{C}$ and $45^{\circ} \mathrm{C}$ respectively.

\section{Determinations of Activation Energy and DLC:}

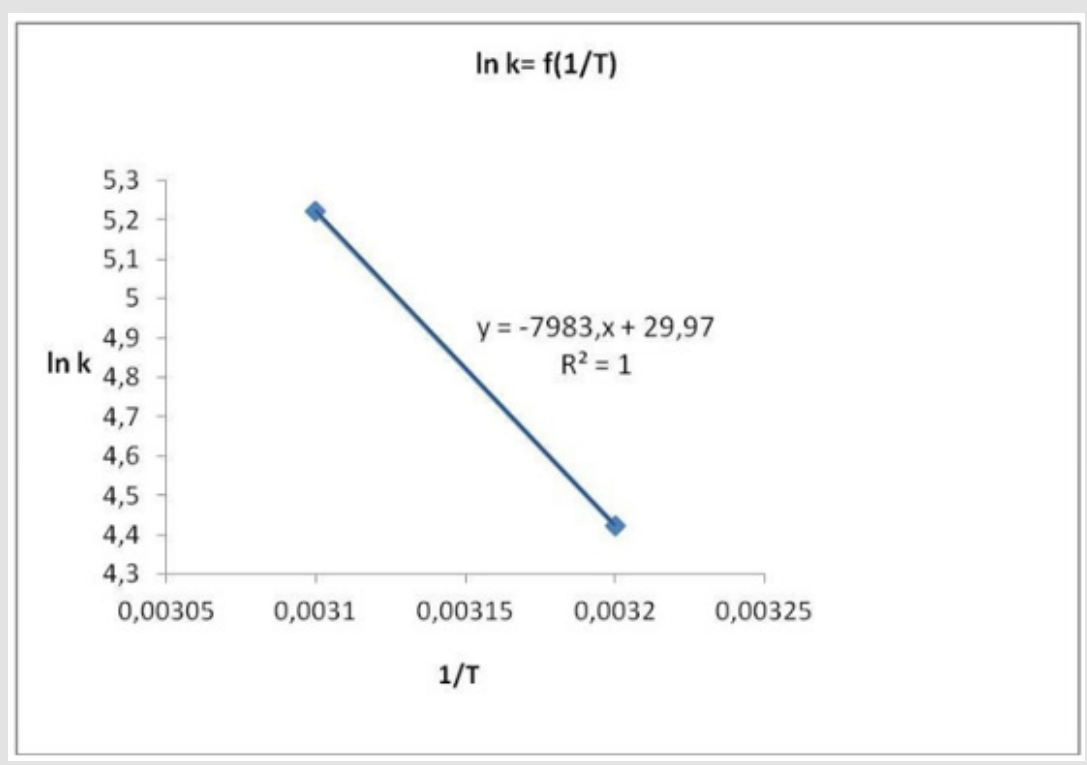

Figure 1b: Ln $k=f(1 / T)$ curve.

Determination of the DLC requires the measurement of the activation energy and the constant K0. For this purpose, the $\operatorname{InK}=$ $\mathrm{f}(1 / \mathrm{T})$ curve was plotted where $(-\mathrm{Ea} / \mathrm{R})$ is the slope of the linear regression line, and LnK0 was originally ordered (Figure 1b). On the basis of the results of the total germ analyses, the determination of the DLC of the product is obtained by equation (2). The values obtained show the activation energy is of about 15862.22 (Cal/g/ mol) for K0 of $10.37^{*} 1012$ which correspond to a DLC of 1198 days at $37^{\circ} \mathrm{C}$. The results obtained enable the DLC of the product to be calculated by considering the evolution of the fungal flora. And thus, counting the total germs in the food produced results in a consumption limit of three years and three months, without the addition of preservatives or other additives.

\section{Conclusion}

Current study is part of the valorization of the red muscles discarded during the processing of tuna in canneries of South Tunisian, in order to obtain a wet food for young dogs. The hysicochemical characterization of these by-products has shown their richness in proteins, fats and minerals, hence the idea of integrating them into animal feed. The low carbohydrate and fibre content leads us to use foods rich in these elements, thus the use of both types of cereals (corn flour and rice flour) : carbohydrates as a source of energy and fibers to have a finished product digestible by the animal. Four formulae were tested using the same manufacturing process. Subsequently, a physicochemical study and a determination of the DLC were carried out. The DLC determined for one of the prepared foods is three years and three months. The physicochemical characterization showed the product's rich protein, carbohydrate and fat content, and consequently it was considered with an important energy value. The composition is also characterized by high concentrations of minerals ( $\mathrm{Mg}, \mathrm{Na}$ ), confirming the nutritional richness of the product. Microbiological analyses were carried out to ensure the safety of the finished product and the results showed the absence of pathogens and the compliance of the product with current standards.

\section{Acknowledgment}

This work is a part of a research by aida karray whose research was supported financially by Ministère de l'enseignement supérieur et de la recherche scientifique-Tunisia through a grant to Laboratoire de Biochimie et de Génie Enzymatique des LipasesENIS.

\section{References}

1. (2014) FAO Organisation des nations unies pour l'aimantation et l'agriculture.

2. (2012) FAO Organisation des nations unies pour l'aimantation et l'agriculture. 
3. Chandra M, Shamasundar B (2015) Rheological properties of gelatin prepared from the swim bladders of freshwater fish Catla catla. Food Hydrocoll 48: 47-54

4. API-BDI (2005) Agence de Promotion de l'Industrie, Annuaire des entreprises industrielles; Base de Donnés Industrielles.

5. Ordón ñez-Del Pazo T, Antelo LT, Franco-Urı́a A, Pe'rez-Martı́n RI, Sotelo CG, et al. (2014) Fish discards management in selected Spanish and Portuguese métiers: dentification and potential valorisation. Trends Food Sci 36(1): 29-43.

6. Blanco M, Sotelo CG, Pe'rez-Martı́n RI (2015) Hydrolysis as a valorization strategy for unused marine food biomass: boarfish and small-spotted catshark discards and by-products. J Food Biochem 39(4): 368-376.

7. Blanco M (2015) Valorizacio'n de descartes y subproductos de pintarroja (Scyliorhinus canicula). Doctoral thesis. Vigo University.

8. JORT (2000) Article 2 du décret $n^{\circ}$ 2000-81 du: JORT; Jornal Oficielle de la Republic Tunisienne ${ }^{\circ} 33$ du 25 avril 2000.

9. Moreno HM, Carballo J, Borderı'as AJ (2009) Study of two different cold restructuring processes using two different qualities of hake (Merluccius capensis) muscle, with addition of microbial transglutaminase. J Sci Food Agric 89(8): 1346-1351.

10. Moreno HM, Borderías AJ, Baron C (2010a) Evaluation of some physicochemical properties of restructured trout and hake during cold gelation and chilled storage. Food Chem 120(2): 410-417.

11. Moreno HM, Carballo J, Borderı'as AJ (2010b) Gelation of fish muscle with transglutaminase added: influence of sodium chloride level and $\mathrm{pH}$. J Muscle Food 21(3): 433-450.

12. (1997) AOAC Association of official Analytical chemists. Official methods of analysis $16^{\text {th }}$ (Edn.), Washington DC, USA.

ISSN : 2574-1241

DOI: 10.26717/BJSTR.2020.29.004759

Aida karray. Biomed J Sci \& Tech Res

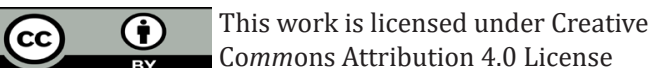

Submission Link: https://biomedres.us/submit-manuscript.php
13. (1990) AOAC Officials methods of analysis. Washington, DC, Association of Official Analytical Chemists

14. (2000) AOAC Official methods of analysis. Washinton DC: Association of official Analytical Chemists.

15. Metcalfe LD, AA Schmitz (1961) The rapid preparation of Fatty acids esters for Gas chromatographic Analysis. ACS Publications 33(3): 363364.

16. Folch J, Lees M, Sloane Stanley GH (1957) A simple method for the isolation and purification of total lipids from animal tissues 226(1): 497-509.

17. Dubois M, Gilles A, Hamiltton J, Rebers P, Smith F (1956) Colorimetric method for determination of sugar and related substances. Analyzes of Chemistry 28(3): 350-356.

18. (1999) Association Française de normalisation NF V 08-201, Microbiologie alimentaire: Aliments des animaux, Examen microbiologique. Ed. AFNOR, Paris pp. 3-7.

19. Wyness L, E Weichselbaum, A O'Connor, EB Williams, B Benelam, et al. (2011) Red meat in the diet: an update, nutrition belletin 36(1): 34-77.

20.https://www.anses.fr/fr/content/poissons-et-produits-de-lap \% C 3\%AAche-synth\%C3\%A 8se-des-recommandations-de1\%E2\%80\%99agence

21. (2014) AAFCO Association of American Feed Control Officials: Dog and Cat Food Nutrient Profiles. AAFCO official publication pp. 4-5.

22. (2008) FEDIAF Nutritional Guidelines for Complete and Complementary Pet Food for Cats and Dogs.

23. Kołodziejska I, Skierka E, Sadowska M, Kołodziejski W, Niecikowska C (2008) Effect of extracting time and temperature on yield of gelatin from different fish offal. Food Chem 107(2): 700-706.

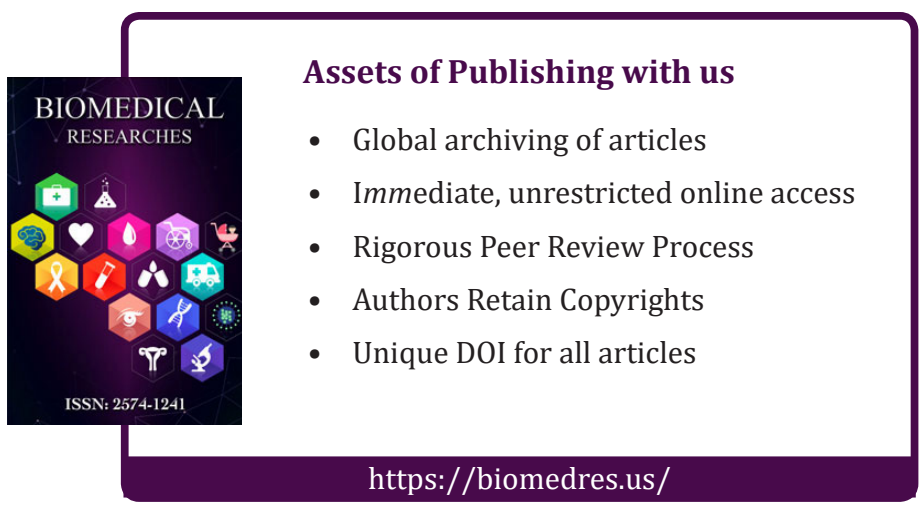

